\author{
AN INTERNATIONAL JOURNAL OF ARTS AND HUMANITIES \\ (IJAH) \\ Bahir Dar, Ethiopia \\ Vol. 3 (3), S/No 11, July, 2014:162-177 \\ ISSN: 2225-8590 (Print) ISSN 2227-5452 (Online) \\ DOI: http://dx.doi.org/10.4314/ijah.v3i3.12
}

\title{
THE PRESENT STATE OF CHILDREN'S LITERATURE IN INDIGENOUS AFRICAN LANGUAGES: THE IGBO EXAMPLE
}

\author{
EZENWA-OHAETO, NGOZI, Ph.D. \\ Department of English Language and Literature \\ Nnamdi Azikiwe University, Awka \\ Anambra State, Ngeria \\ E-mail: nezenwaohaeto@gmail.com
}

\begin{abstract}
This work tries to explore the state of children's indigenous literature at both nursery and lower primary levels of education in Igbo speech community of Eastern Nigeria. As a result of the perceived decline in proficiency in both oral and written forms of the language among the younger generation of 'Ndigbo' and which has given rise to obvious fear of the language degenerating to a state of endangerment, some committed individuals and groups have organized and are still organizing significant language crusade against the prevalent negative language attitude of 'Ndigbo' towards their language. This effort, it is hoped, will engender the infusion of the spirit of revitalization and rebirth and the eventual language pride into the owners of Igbo language. It is a well known fact that Children's literature provides opportunity of response, appreciation and internalization of one's cultural heritage as well as the nurture, growth and development of the children's self perception and language skills which result to the internal urge of transferring same to posterity. In view of these,
\end{abstract}


this study explores the extent the language crusade at present going on in Igbo society has really actualized the targeted goals, and inquires whether the crusaders also have early childhood education (nursery and lower primary) in mind as part of their targets. This study will equally examine the current state of the indigenous children's literature: prose, poetry, drama, including nursery rhymes at this crucial formation stage in relation with the existing school curriculum. With the fact that early exposure of children to indigenous literature is one of the major measures of revitalizing and stabilizing languages, this research will premise its search on Fishman's theoretical framework for language revitalization and shift. Based on the findings, some recommendations will be made and some relevant revitalization techniques also be suggested.

\section{Introduction}

Literature in its various forms has been noted as one vital means through which readers encounter and experience creativity. It not only provides avenues for artistic manipulation of language which, in turn, fosters unconscious processes of internalization of not only the approaches to language acquisition that occurs basically informally, but also gives the way to experiencing and exploring diverse cultures to which a writer might choose to take the reader to. The resources of literature have equally proven a reliable channel of engendering and transferring cultural heritage and identity to posterity using the inherent entertainment and relaxation opportunities it provides. So many values are attributable to literature. Aside the enjoyment often associated with it, it equally "takes readers beyond everyday experiences, broadening their world knowledge, developing their imaginations and senses of humour, and enabling them to grow in humanity and understanding" (Galda, Ash, \& Cullin,2001 as quoted in Stoodt-Hill \& AmspaughCarson, 2).

Because literature provides enjoyment and relaxation, it has become a veritable tool for inculcation and internalization of moral and ethical principles, norms, cultural ideals, identity and heritage into children. A good children's or juveniles' literary text can through its captivating quality, impact on a child so deeply that he/she unconsciously identifies with it in his/her personality, identity, self perception, his/her world view in general and the immediate environment in particular. Smith observed that "... good children's literature arouses a child's imagination and extends his horizon giving him a knowledge of the past in relation to the present and imbuing in him ideals and values necessary for national development" (Web). Africans do not basically demarcate art from education; they rather perceive the entertainment quality of art as an irrefutable means to more valuable ends. African writers often draw from the wealth of their oral literature. They use entertainment to aid in communicating 
essential truths, educate and inform the general community. With regards to children's literature, Nwapa enthused that "...to be amused and intrigued and taught is the most a child can expect from a book" (268). Before the advent of formal education, Africans achieved these ends via the instrumentality of their indigenous languages which had been part and parcel of their daily living and through which their values; ideologies, culture, beliefs, practices and education have been "incised into the skin, and written in their hearts, veins, and senses right from infancy..." (Ejiofor 70). By so doing, they were able to sustain as well as transfer their culture to posterity via their language heritage.

African nations, through history, suddenly were confronted with situations that demanded acquiring and learning of foreign languages. The outcomes of this situation are acquisition of foreign cultures, foreign ideologies, foreign beliefs, foreign practices and above all, foreign education which came with foreign literature written in foreign languages to which African children have been exposed to over decades. This situation produced generations of Africans that have internalized foreign cultural ideals to the detriment of both their languages and their accompanying literatures; generations that have lost their cultural understandings. Formal education in most African countries particularly in Nigeria, has unfortunately, been equated with good command of either English or any of the languages of the colonial masters. Anything short of that is interpreted as illiteracy and a credit pass in the foreign language is an endorsed license for further education. The situation completely ignores the fact that " there are people who are very good in understanding by means of L1 while finding it very difficult to do so by means of L2" ( Ewelu 262). To that end children's literature used in Nigeria, precisely, in schools within the Igbo speech community, are English based which contain, mostly, foreign ideas and views of reality. Some of them try to present African realities in English language and by so doing, ignore the fact that cultural differences prevent one language from possessing the linguistic capacity to express and represent the ideals, objects and philosophy of another language. Such is the situation between English (or any of the colonial masters' languages) and Igbo language. The consequences are Igbo children whose natural perceptions are geared, as early as their formative stage, towards adoption and internalization of foreign culture which in turn distort their personality. Ewelu rightly observed that "to abandon one's language is to abandon one's culture and one's proper world; it is to do away with one's terminus a quo..." (260). What led to this attitude of abandonment is a question that should be answered.

\section{The Genesis of the Problem}

It is often said that there is no smoke without fire. When a stream is dirty from its source, one can only imagine its state down the stream. Achebe rightly stated that 
"...one who does not know where the rain began to beat him cannot say where he dries his body" (1). One tends to believe, in this case, that the Igbo know where the rain began to beat them and in fact, they are not only the rain makers but also they chose to stand right outside the cover of their homes and gave the 'rain' the free hand to beat them very thoroughly and they got soaked right to their undies. The big question may be whether the present generation of 'Ndi Igbo', actually know where, when and why they should dry their bodies now.

It is a common belief that our language problem started with the coming of the white man. Ezeani, somehow, belongs to this group. He feels that the linguistic situation is answerable for the prevalent underdevelopment of ex-colonial African countries. He cited Japan as a good example of a country that has recorded socio-economic development because they were "not encumbered by the chains of linguistic imperialism" (193). While citing Rodney, Ezeani further stated that:

It is overt that most African countries still remain culturally, economically, politically and educationally underdeveloped after many years of benefiting from Western Education and despite being fluent speakers of English and Fresh languages. The situation seems to justify Rodney's... designation of colonial education system as 'education for underdevelopment'. 'It was not an educational system designed to give young people confidence and pride as members of African societies but one which sought to instill a sense of deference toward all that was European and capitalist (193).

If the above argument is to stand, one may wonder then why our co-nationals; Hausa and Yoruba and other linguistic groups in Nigeria still proudly speak their languages anywhere and at anytime even when they are interacting with members of other linguistic origin and expect them to understand them. Many of them have literature written in their languages. Another school of thought believes that the Igbo's attitude to their language is an aftermath of the Nigerian-Biafran war which came about as a survival strategy in the demeaning economic and sociopolitical situations they found themselves in the post Nigeria-Biafran war. They would rather speak English, Yoruba or Hausa as long as they met their needs. Others are of the view that a typical Igbo person is an unrepentant imitator and would prefer anything foreign, language and literature inclusive, to what belongs to him/her naturally and in fact "contemporary Igbos have summarized their scorn of what Igbo stands for by coining the word 'Igbotic'. Igbotic stands for anything crude, uncultured, uncivilized... (Ejiofor 22). This is more prevalent among the first crop of educated Igbo people who perceive 
everything English as a class indicator, a means of image booster. While writing on this issue, Ejiofor further recorded that:

some of the first Igbos to travel overseas for higher education returned after some years pretending they could no more speak the Igbo language well. While their Hausa, and to a less extent their Yoruba counterparts, abandoned the Western suit in Briton seaports to the cold winters of England and Scotland, and returned to the cap and gown of their fathers, most of our people came back parading their woolen suits in the humidity and heat of Igboland. The notable exception was Mazi Mbonu Ojike of blessed memory (21).

These set of people actually set the standard for which education was measured in Igbo land then. Some of them became writers of Igbo and African literature in English. This was accompanied by mass importation of foreign children's literature into the speech community, followed by the attendant children's early exposure to foreign literatures at their schools, homes, churches and on the electronic media.

The most damaging factor to our indigenous literature is what is obtainable in most families where speaking of indigenous languages and the consequent reading of the accompanying literature has become almost a taboo. In most Igbo homes, speaking of English has become a sort of unwritten rule. Igbo is not spoken at all. This also means that Igbo books are not used in such families. Some parents do that as a way of showing 'modernity' and the belief that English language is superior to Igbo. If Chomskyan theory of language universals is something to go by, such parents should know that all languages of the world are basically equal since, apart from sharing basic grammar, phonology, morphology and semantics in common, they are all used for communication purposes. Some of the parents equally give the excuse that they would not want their wards to write university entrance examination more than once, therefore, they start in time to expose their children to English language by instituting English in their homes as the means of communication (L1). Such parents actually are acting out of ignorance. The exposition of children to L1 (indigenous language) does not, in any way,hinder the eventual learning of L2, at least, not in any other language level other than phonetics and to a lower extent for that matter and it does not hinder neither the performance nor competence in L2. Moreover, since most members of the speech community interact in the mother-tongue, the child loses out in communication and learning of the Igbo registers and general spheres of the larger society, thereby becoming deficient and limited in the Mother-tongue vocabulary. A child who communicates in his/her mother-tongue at home and who is exposed to indigenous literature early enough becomes rich in MT (Igbo) vocabulary and 
structure. At school when he/she is later exposed to L2 (English and its literature) will be confident in content education. In fact, research has proved that "school-based second language teaching has not led to widespread 'communicative competency' (the ability to carry on a sustained conversation) in the new language for most students" (Reyhner, Web). UNESCO/Vietnam report made in 1998 and as recorded by Ezeani reports that "research around the world has shown that literacy skills are best acquired in the mother-tongue and then transferred to the second language, resulting in increased proficiency in both languages" (166). Some parents, especially, the younger ones admit that they do not know the language either and so cannot give what they do not have. This is where the implementation of the language policy will be more than helpful. If the children from this type of family are exposed to both the language and its literature at school, and with the help of socialization with their mates, they will turn out to be Igbo language teachers to their parents. This group of parents is also advised to send their children to their grandparents during holidays.

Some schools can also engage the services of the elders who are very fluent speakers of Igbo language and who have deep knowledge of the culture to interact with the pupils at stipulated time and place. The mothers, in addition to handling other statutory domestic chores, should also handle issues like teaching children the recipe for cooking traditional food too.

Research has also, confidently, proven that the family is the bedrock of every language and many endangered languages' heritage has been revived by making the language "part of their homes and their daily lives, despite all the pressures against doing so. And it is for families who might wish to do this brave act themselves" (Hinton xiii). Hinton also noted that there is no doubt that the home is the "primary place where first language acquisition occur..."(xiv). Reyhner also reiterated Fishman's belief "that the intergenerational transmission of language in the home from parents to young children is the key to indigenous languages' lives". Reyhner also echoed Fishman stance that "the road to societal death is paved by language activity that is not focused on intergenerational continuity... He cautions against putting too much effort and reliance on native language media ... but they are no substitute for grassroots efforts focused on using indigenous language in homes and at community social occasions". He however noted that: schools can play either a positive or negative role in supporting the efforts of indigenous parents and communities" (Web).

Another crucial factor that led to the present indigenous language situation and which is affecting the indigenous literature adversely is the disappointing and shameful refusal/inability to implement the language policy aspect of the National Policy on Education (NPE) by Nigerian government. Interestingly, the said policy which was 
revised in 1981 and as recorded by Okediadi recognized the importance of formal instruction via indigenous language at pre-primary and lower primary levels when it states that:

in addition to appreciating the importance of language in the education process, and as a means of preserving the people's culture, the Government considers it to be in the interest of national unity that each child should be encouraged to learn one of the tree major languages in Nigeria to be Housa, Ibo and Yoruba....To achieve the... objectives (of pre-primary education), Government will ensure that the medium of instruction will be principally the mother-tongue or the language of the immediate community...(10)... Government will see to it that the medium of instruction in the primary schools is initially the mother-tongue or the language of the immediate community and, at a later stage, English (41). (Emphases are mine).

The above policy clearly exposes the good intention of the government of Federal Republic of Nigeria but which has, unfortunately, remained not only a lip service but also a 'paper service' since its promulgation. The obvious inability of the government to implement this good policy has resulted to many problems especially the unhealthy exposure of our children to foreign literature at their formative age at the detriment of our indigenous one and our eventual inability to transfer our cultural heritage to them.

The Consequences of Premature Exposure of our Children to Foreign Literature

Obviously, the Igbo attitude to their language has far more reaching negative consequences especially as it concerns children's premature exposure to foreign literature. Ranking high among numerous others is the fact that the child who had acquired a mother-tongue will be struggling between grasping the rudiments of the foreign language and the subject matter of the literary text and most often the subject matter is sacrificed at the 'sacred' alter of the language. This has resulted to a situation where a greater number of our children who can speak reasonably good English failed examinations that require answers in the same language. Anyidoho completely agreed with this difficult situation of the African child when he said, in an interview, that "....in a typical classroom situation you had to struggle with gaining control of the grammar and the sound system of English and at the same time being forced to assimilate poetry in a very rigid way" (277). Ezeani also bemoaned this trend when he cited the stand of The Centre for Applied Linguistics at the University of Warwick (CAL 2001), thus: 
If school authorities and parents had understood the importance of mother-tongue education as a necessary foundation for academic progress and mastery of a second language; if they had understood the difficulties children faced in learning a second language for academic purposes, they would have exhibited a positive attitude to the mother-tongue as a medium of education. 'They believe that children learn languages easily, and they have confused process of learning a language with that of learning through a language' (166).

Ezeani also stated the stand of another concerned organization, SIL International: Partners in Language Development, who maintained that:

when the language of instruction is not the mother-tongue, double demands are placed on the learner; first the demand of language acquisition and second that of literacy learning. For this reason, rather than forcing that double burden on the learner, SIL recommends starting with literacy in the mother-tongue both for instruction and for the content of the materials. The reason for this is that most people are disadvantaged if they do not have the opportunity to learn in a language they best understand (167).

Reading and digesting a gist of a literary text in a second language is not an easy task especially when one is doing that in a different linguistic context. Fafunwa et al state that " while some of the native speakers of English or French have problems of understanding their own language as dramatized in a popular book entitled: Why Jonny can't read, the African child has all of Jonny's linguistic problems plus his own, thus suffering from double jeopardy (cited in Ezeani 167).

Because of the nature of Western Education to which the majority of the literary writers of Igbo descent were exposed, many of them do not possess the desired critical understanding of their Igbo background and as a result, they cannot as well critically analyze it, therefore they sought solace in writing in English for children who have a total different mother-tongue. If we accept that language is an identifier of one's identity, a pointer to ones cultural affiliation and heritage, we can then begin to appreciate the consequences of the regrettable deprivation of Igbo children's access to literature written in their mother tongue. This, undoutably, does not only amount to child abuse in the highest order but deprivation of one's birth right. Doe Baird contemplates that "maybe we do not realize that our children have a birthright to their language (23). Ewelu, while lamenting over this situation in relation to Western Education in general, captures it aptly: 
the structure and policies of formal education in African countries are in such a way that on stepping into the school; the student is snatched away from his/her cultural background and catapulted to the "heights" of Western cultures. On attaining to the heights of this other culture, he/she discovers that he/she is a foreigner to it. Two alternatives are open to him/her: he/she may choose to sail along in this foreign culture with all the identity crises that go with it; or he/she chooses to rediscover his/her identity as African. If the later is his/her choice, he/she is confronted with still another problem. He/she sees that there is no equilibrium between his/her Western education and his/her knowledge of his/her native African culture. In his/her effort to identify himself/herself with African way of life, he/she falls back to myths and superstitions, because his/her education failed to teach him/her how to rationally and critically evaluate his/her African background. The result is a schizophrenic personality, as personified in Obi Okonkwo of C. Achebe's No Longer at Ease... (324)

It is obvious that Ewelu is concerned here with a child who is of the age of making decisive choices for him/herself. On the contrary, I am talking of Igbo children of kindergarten /nursery or lower primary formal education age, who practically cannot make any choice for themselves other than what the society, either through educational policy, has made provisions for or their parents or what the private school proprietors understood to be educationally fashionable. The children are completely helpless. At this critical formative age he/she is forcefully immersed into prearranged programme(s) to which he/she has no say. He/she starts to memorise foreign rhymes, poems, and songs etc which were pre-designed to build into the child's subconsciousness thereby, creating imaginations that are beyond his/her immediate environment and which are highly damaging to the child's cultural identity. While advising on this trend, Wilson-Tagoe noted that "a writer of children's books should, in my view, be aware... of the mind, psychology and understanding of the child as well as his/her particular relationship to language either in the oral or written form"(18). Wilson-Tagoe went on to ask pertinent questions: "Do we want to give our children just any reading material ... or do we want to give them literature that would please them, stimulate their imagination, build up their sensibility to experience of all kinds, develop their perceptive power and help them to grow up in a cultural environment that is not just static but responsive to a growing African and international world?" (20). 
Another damaging effect is that of a child who is immersed into (a) foreign language from the home and who is enrolled to a school where a foreign language is the medium of instruction and where indigenous literature does not exist. It does not stop there. In the child's church also, every business is done in a foreign language! The question about this child rallies around the nationality of origin.

It is important to note that culturally, this child is neither here nor there since it is almost impossible to attain a native-like proficiency with the accompanying culture of a language in an L2 environment. This child can only be likened to a bat; neither a bird of the day time nor that of the night. Culturally he/she belongs absolutely nowhere.

\section{Attempts to Salvage the Bad Situation}

In the period 1800-1875, the first generation of literate West Africans made a significant contribution to the study of their languages. But since then, very little has been done by West Africans... This failure to continue and extend linguistic study is particularly disappointing. Are the present institutes of higher learning in West Africa doing all they can, not only to encourage the study of local language but to see to it that this study is undertaken, not only by foreign students, but to an increasing extent by those to whom the languages are a mother tongue? (Dr. Abraham, cited in Ejiofor 102).

Ejiofor, in one of his books dedicated to the revival of Igbo language asked, albeit rhetorically; "Igbo Language: is it a tongue without a mouth? Surely it looks like a dying Language of a living people" (98).

Some organizations, both governmental and non-governmental, have made recognizable efforts towards reinvigorating Igbo consciousness. Organizations such as 'Otu Subakwa Igbo', which literarily means 'Keep speaking Igbo', and which was founded and championed by Prof. Pita Ejiofor. Igbo Studies Association and so many others have, in various forms, contributed immensely, to the current crusade in Igboland targeted at revitalization of Igbo language. "Otu Subakwa Igbo" often organizes lectures at various forums on the issue. These lectures have given birth to some books authored by Prof. Pita Ejiofor himself. The Igbo Studies Association has, in its numerous international conferences, dedicated its resources to the same goal. There is also in existence Igbo Renaissance domiciled in Gregory University, Uturu to which Prof. Ihechukwu Madubike is the Director. Madubike has to his credit a lot books dedicated to linguistic and political course of Ndi Igbo. Anambra State 
government has also made it a law that Igbo language be the language of interaction in all offices on Fridays.

Likewise, some writers of Igbo decent have also made their contributions by writing children's literature. These books were randomly selected. Such books as Prof. Ernest Emenyonu's "Uzoechi: A Story of African Child" (prose in English). Akachi Adimora-Ezeigbo's "Cloud and Other Poems for Children" (poems in English), Lizi Ashimole's "The Maiguard \& the Maigida" (prose in English), Cyprian Ekwensi's "Tortoise and the Monkey"(Prose in English), G.C. Obodoechi's "Adventures of the Tortoise and Other Animals (prose in English), John N.J. Okafor's "The King's Crown" (prose in English) and Anezi Okoro's "The Second Great Flood" (prose in English). Ifeoma Onyekwelu's "A is for Africa" and others (prose in English).These are stories about Africa written in English, basically, for children of Igbo descent and for Nigerian children in general. With the exception of Chinedu Ofomata's "Okwu Ndu (Abu Umuaka)" (collection of Igbo poems), it is important to note that Ofomata has some other Igbo literature books for children but unfortunately, none of them is targeted at the group of the children that constitutes the population for this study.

\section{Population Sample for the Study}

Six government-owned nursery/primary schools and six private nursey/primary schools, and two missions owned nursery/primary schools, all in Awka, the capital city of Anambra State, an Igbo State, were randomly selected for this study. It was discovered that in all the private schools, (at nursery and lower primary levels), the pupils communicate and are taught in English. They learn only English rhymes, there were no Igbo poems or novels for the lower primary sections but they in one of the government-owned school I found one Igbo reader "Uto Igbo maka Ntakara", which does not contain any Igbo rhyme nor poems. It was also discovered that they say their opening and closing prayers in English. Prayers were never said in Igbo language!

What is very baffling about the language situation in the schools I visited in Igbo speech community is that most of the proprietors accepted the fact that what they are doing is not good for the children and the nation but they claimed that they are into business and out to satisfy the parents of the children under their care. When I requested for Igbo rhyme books and story books for the nursery and lower primary sections, some of them could not hide their consternation at what one of described as 'amazement' at my request. She asked whether it is necessary to start exposing them to Igbo books at this level. On the contrary, they have English rhyme books and children's stories in abundance. They also have English children's films in abundance, the types of 'Tom and Jerry' and many others. None is of Igbo language. 
I also visited one school with the name "Bilingual education... ', hoping that I have at last found one school that may understand the benefits of bilingual education but that was never to be. The name 'Bilingual school' is just an appellation. It is completely not in practical terms.

My visit to Anambra State Universal Basic Education (ASUBED) was revealing. It was discovered that at nursery and lower primary level which are supposed to be the foundation levels, there is no recommended Igbo rhyme books, children's stories of any sort or children's Igbo films. All the books recommended were of the English language.

\section{Theoretical Framework}

Based on the fact that Igbo language is not totally in a state of extinction, this study premised this work on the first six stages of Fishman's eight stages of suggested intervention to strengthen language. The reason is that the six stages directly address the linguistic situation of the Igbo language.

This study therefore suggests stages one to six of Fishman's suggested interventions to strengthen language as recorded by Jon Reyner, as a major way of reviving and strengthening not only Igbo language but all African languages that are experiencing language imperialism.

Current Status of Language

Stage 1: Some language use by higher levels of government and in higher education.

Stage 2: Language is used by local government and in the mass media in the minority community.

Stage3: Language is used in places of business and of employees in less specialized work areas.

\section{Suggested Interventions to Language}

Teach tribal college subject matter classes in the language. Develop an indigenous language oral and written literature through dramatic presentations and publications. Give tribal/national awards for indigenous language publication and other notable efforts to promote indigenous languages.

Promote use of written form of language for government and business dealings/records. Promote indigenous language newsletters, newspapers, radio stations, and television stations.

Promote language by making it the language of work used throughout the community (Palmer,1997). Develop vocabulary so that workers in an office could do their dayto-day work using their indigenous language... 
Stage 4: Language is required in elementary schools.

Stage 5: Language is still very much alive and used in community.

Stage 6: Some intergenerational use of language
Improve instrumental methods utilizing TPR (Asher, 1996), TPR- Storytelling (Cantoni, this volume) and other immersion teaching techniques. Teach reading and writing and higher level language skills (Heredia \& Francis, 1997). Develop two-way bilingual programs where appropriate where non-speaking elementary students learn the indigenous language and speakers learn a national or international language. Need to develop indigenous language textbooks to teach literacy and academic subject matter content.

Offer literacy in minority language. Promote voluntary programs in the schools and other community institutions to improve the prestige and use of the language .Use language in local government functions, especially social services. Give recognition to special local efforts through awards, etc.

Develop places in community where language is encouraged, protected, and used exclusively. Encourage more young parents to speak the indigenous language in home with and around their young children

(Web)

\section{Reviving our Igbo Children's Literature from its Present State}

At an Igbo cultural carnival, 2013, organized at Gregory University Uturu, Prof. Ihechukwu Madubike, who described Igbo language as the "soul of the culture of Ndigbo" and that "the disappearance of the language would mean the ultimate death of the culture" (Web), announced that the university has plans of introducing the Igbo language as a compulsory subject for all students in the second year. As noble as this plan might look to the ongoing crusade towards reviving Igbo language, it will not yield the desired goal. This is because, at this stage, most of the students must have attained lateralization (surpassed receptive abilities) stage of their language acquisition life. My stance is that mother-tongue acquisition and the exposition of its literature should start at infancy and that Igbo literature should be introduced at nursery and lower primary levels so as ensure reliable and effective acquisition of the 
language and its culture which our children should be proud of. To this effect, Reihner has rightly pointed out that "... for language revival efforts to be successful, children need to feel that it is "their" indigenous language and that speaking the language makes them a member of an important and worthwhile group"( Web).Doing this early enough is the onus of this study, therefore the following are suggested to help in the process:

The government must take the lead step by living up to its responsibility. The Federal government of Nigeria has put in place a good educational policy that could serve as the stepping stone if well handled. All it requires to do is to put up strong machinery that should enforce its implementation. Already, there are existing inspectorial bodies in the country but it seems they are not living up to expectations too. Therefore, the government should institute a regulatory body whose responsibility should be to checkmate the activities of the inspectorate and school authorities towards implementation of the policy. Government should also insist on the use of the language of the immediate community for instruction at these developmental stages of our children. This will directly impact and motivate creative writers on the writing and production of Igbo literature for, especially, these formative classes. For Government to achieve these English language must seize to be language of instruction and Igbo language should take up that position. It (English) should rather be taught as a subject only. The government can also afford to sponsor writers of children's books and take up the distribution of their works free to every home and school.

The government should also sponsor the translation of the already existing children's literature written in English to Igbo language and to other indigenous Nigerian languages. This will go a long way in exposing our children to old and new Igbo concepts that will build their Igbo vocabulary power and also build their cultural knowledge and understanding. Writers who can afford to translate their books can also help in reviving our heritage. Our actors should also be encouraged by providing them with the required training and facilities that will equip them in the production of children's films in Igbo language while they will be made to understand the importance of telling Igbo stories using Igbo language.

I talked earlier on engaging the services of the elders (both men and women) who have reasonable command of Igbo language and are conversant with the culture. This can be done as holiday programme where they can teach our children more of the Igbo rhymes, games, sports, stories and names of our traditional food and their nutritional values. The organizations should also carry their crusades to nursery and primary sections so as to ensure that they capture our children early enough. 
Moreover, this is an era of electronic communication and both children and youths all over the globe have become ardent users of opportunities it provides. Igbo linguists and the government should therefore liaise and come up with both print, and more importantly, online children's dictionary with which our children and even adults can check up Igbo words and expressions they find difficult to understand. This has become pertinent because with their mobile phones they can easily access them. Moreover, this will provide high visibility and prestige for Igbo language.

\section{Conclusion}

One can conclude by stating that no other person can revive our language for us and there is no other way of doing it successfully other than by being very committed to getting our children when we can still do it. Our government has no other responsibility than instilling in our children the pride of self and of their culture through indigenous literature. Parents are at the core of the matter. If they re-direct their children at home, the general Igbo language and culture will be better for it. We look forward to more rewarding productions from our writers, actors and actresses towards reviving our language and culture. Finally, this paper agrees completely with Baird's assertion, thus; "I have thought about all of these things and felt the emotion from these thoughts too. I also know that if I put out the language I do have, then I have given my child everything I have. I have given her a chance and can feel satisfied with my efforts to pass on my culture." (23).By exposing our children early enough to Igbo literature, we are taking the right step towards making Igbo language very operational and making our children culturally correct.

\section{Works Cited}

Achebe, Chinua. There was a Country. London: Penguine Books, 2012.Print.

Anyidoho, Kofi by Raoul Granqvist. There is a Child in Every Adult and an Adult in Every Child. Preserving the Landscape of Imagination: Children's Literature in Africa. Raul Granqvist. Ed. Amsterdan: Rodopy. (1997): 265275. Print.

Baird, Jesie L.D. "How did this Happen to my Language? Bringing our Languages Home: Language Revitalization for families. Leanne Hilton; Ed. California: Heyday. (2013): 19-30. Print.

Ejiofor, Pita. Cultural Revival in Igboland. Enugu: Nolix Educational Publications (Nig), 2002. Print. 
Ewelu, Benjamin I. Language and Thought: A Problematique in African Philosophy. Enugu: Delta Publications, 2010.Print.

Ezeani, Emefiena. A Philosophy of Education for African Nations: Recovering from the Negative Effects of Colonial Education. London: Veritas Lumen Publishers, 2013. Print

Hinton, Leanne. "Introduction". Bringing Our Languages Home: Language Revilitalization for Families. Leanne Hilton; Ed. California: Heyday. (2013): xiii.

Nwapa, Flora. "Writing and Publishing for Children in Africa". Preserving the Landscape of Imagination: Children's Literature in Africa. Raoul Granqvist and Jurgen Martini; Eds. Amsterdan: Rodopy. (1997): 265-275. Print.

Okediadi, Nkechinyere."Literacy in the Mother Tongue:Policy Versus Preference".In the Perspective of Language \& Literature: Essays in Honour of R.U Uzoezie. Ngozi Ezenwa-Ohaeto and Ifeyinwa Ogbazi; Eds.Rex Charles \& Patrick Publications (2011): 39-49.

Reyhner, Jon. "Some Basics of Indigenous Language Revitalization". Revitalizing Indigenous Languages. n.pag. Web: jan.ulc.nau.edu/njar/RIL_9.html. Jan.9, 2014.

Smith, Arthur. The Present Situation for Writing and publishing Creative Writing for Children in Africa. n.pag. Web. 16 March 2014.

Stood-Hill, Barbara .D and Amspaugh-Corson L. Children's Literature: Discovery for a Lifetime. $\left(4^{\text {th }}\right.$ edition).Boston: Pearson Education, Inc, 2009.

Vanguard Newspaper. "University to Make Igbo Language Compulsory Course for all Students" http://www.vangurdngr.com/2013/12/university-make-igbolanguage-compulsory-course-students

Wilson-Tagoe, Nana. "Children's Literature in Africa; Theoretical and Critical Issues". Children and Literature in Africa. Chidi Ikonne, Emelia Oko and Peter Onwudinjo.Eds. Ibadan: Heinemann Educational Books. (1992):1823.Print. 